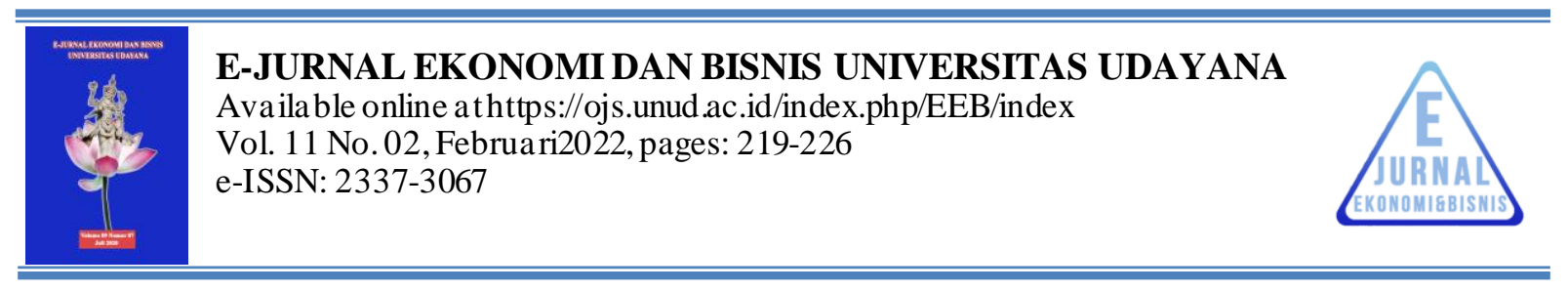

\title{
PENGARUH INSENTIF PAJAK, KUALITAS PELAYANAN, DAN PEMAHAMAN PERPAJAKAN TERHADAP KEPATUHAN WAJIB PAJAK UMKM
}

\author{
Ni Luh Putu Norma Dewi Abdi Pradnyani ${ }^{1}$ Putu Ratih Sasmitadewi ${ }^{2}$ Putu Adi Suprapto ${ }^{3}$
}

\begin{tabular}{ll}
\hline Article history: & Abstract \\
\hline
\end{tabular}

Submitted: 20 Oktober 2021

Revised: 19November 2021

Accepted: 14 Desember 2021

\section{Keywords:}

Tax Incentives; Quality of Service; Taxation Understanding; Tax Compliance

\section{Kata Kunci:}

Insentif pajak; Kualitas pelayanan; Pemahaman perpajakan; Kepatuhan pajak;

\section{Koresponding: \\ Politeknik Negeri Bali, Bali, Indonesia Email:normadewi27@pnb.ac.i $d$}

Tax revenue has notbeen maximized and the tax ratio is still low because the level of compliance of MSME taxpayershas decreased. In the conditions of the Covid-19 pandemic, Direktorat Jenderal Pajak provides tax incentivesto maintain compliance during the Covid-19 pandemic. The purpose of this study was to determine the effect of taxincentives, qualityof service, and taxation understanding on MSMEtaxpayer compliance. The type of data used in this study is primary data obtained through a questionnaire. The sample in this study was based on the accidental sampling method with a sample of $100 M$ MME taxpayers registered at KPP Pratama Badung Selatan. The statistical test used to test the hyp othesis is Structural Equation Modeling (SEM) based on Partial Least Square (PLS) with SmartPLS 3.0 media. The results of this study indicate that tax incentives, quality of service, and taxation understanding have a positive and significant impact on MSMEtaxpayer compliance.

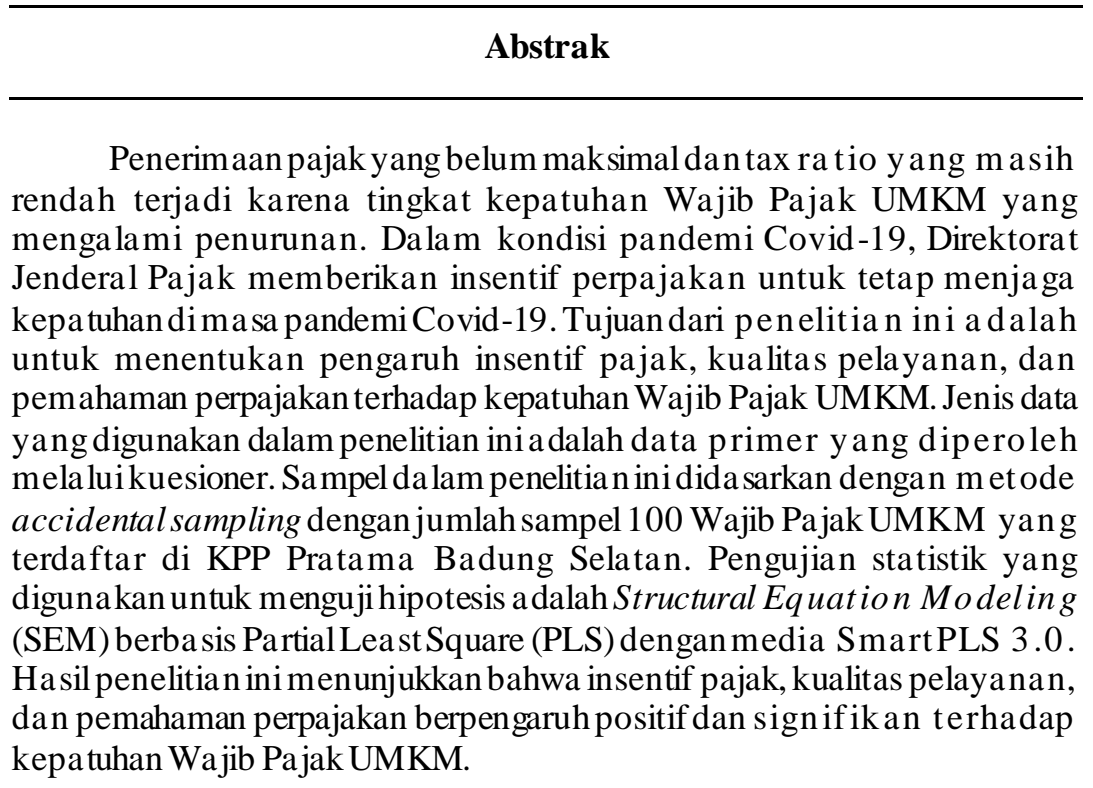

Politeknik Negeri Ba li, Ba li, Indonesia ${ }^{1}$

Email: ratihsasmita9@gmail.com

Politeknik Negeri Ba li, Ba li, Indonesia ${ }^{2}$

Email: adisuprapto@pnb@ac.id 


\section{PENDAHULUAN}

Meningkatnya jumlah belanja pemerintah dalam rangka pendanaan negara menuntut peningkatan pendapatan negara. Dua sumber utama penerimaan dimiliki oleh pemerintah yang tertuang melalui pedoman Anggaran Pendapatan Belanja Negara (APBN), yaitu sumber pendanaan luar negeri dan sumber pendanaan dalam negeri. Sumber pendanaan dalam negeri berasal dari sektor non pajak dan pajak. Pendapatan negara tahun 2020 mencapai 1.699,9 triliun dengan penerimaan pajak sebesar 1.404,5 triliun, sedangkan tahun 2021 pendapatan negara ditargetkan sebesar 1.743,6 triliun dengan penerimaan pajak sebesar 1.444,5 triliun (www.kemenkeu.go.id). Proporsi dari penerimaan tahun 2020 dari sektor pajak dalam struktur APBN mencapai 82,6\% dari seluruh penerimaan negara dan target penerimaan tahun 2021 meningkat dari sektor pajak sebesar 82,8\% dari seluruh penerimaan negara. Pajak menjadi komponen penting pemerintah dalam memperoleh pendapatan untuk penyediaan layanan kepada warga negaranya (Appah \& Wosowei 2016).

Kementerian Keuangan Republik Indonesia melalui Kepala Badan Kebijakan Fiskal (BKF) mengungkapkan bahwa akan menggali potensi perpajakan dari sektor Usaha Mikro Kecil dan Menengah (UMKM) yang nantinya diharapkan dapat mendorong rasio pajak Indonesia (www.cnbcindonesia.com). Pulau Bali sebagai bagian dari provinsi di Indonesia merupakan daerah yang terkenal dengan pariwisatanya, khususnya di Kabupaten Badung. Lonjakan jumlah UMKM terjadi akibat sektor pariwisata yang selama ini menjadi mata pencaharian utama di Kabupaten Badung bagian selatan tidak beroperasi (www.bali.bisnis.com). Peningkatan jumlah UMKM yang signifikan dapat dilihat pada jumlah Wajib Pajak UMKM yang terdaftar di Kantor Pelayanan Pajak (KPP) Pratama Badung Selatan. Pada tahun 2019, jumlah Wajib Pajak UMKM yang terdaftar yaitu 27.408. Lalu jumlah Wajib Pajak UMKM mengalami peningkatan pada tahun 2020 sejumlah 48.910.

Peningkatan jumlah Wajib Pajak UMKM tidak sejalan dengan angka kepatuhan Wajib Pajak UMKM yang terdaftar di KPP Pratama Badung Selatan. Tabel 1 menunjukkan angka kepatuhan Wajib Pajak UMKM yang terdaftar di KPP Pratama Badung Selatan:

Table 1.

Angka Kepatuhan Wajib Pajak UMKM yang Terdaftar di KPP Pratama Badung Selatan

\begin{tabular}{cc}
\hline Tahun & Angka Kepatuhan \\
\hline 2017 & $69,60 \%$ \\
2018 & $120 \%$ \\
2019 & $120 \%$ \\
2020 & $72,44 \%$ \\
\hline
\end{tabular}

Sumber: KPPPratama Badung Selatan, 2021

Penurunan angka kepatuhan menunjukkan adanya indikasi kurang patuhnya Wajib Pajak disebabkan oleh kurangnya kesadaran dan kepatuhan Wajib Pajak (Listyowati \& Suhendro 2018). Penerimaan pajak seperti yang diharapkan tercapai jika didukung oleh kepatuhan oleh seluruh Wajib Pajak dalam memenuhi kewajiban perpajakannya. Kepatuhan Wajib Pajak diyakini sebagai poin penting bagi pemerintah karena kepatuhan pajak yang rendah berimplikasi pada penurunan pendapatan pajak yang pada akhirnya akan menghambat pembangunan nasional.

Kemungkinan ketidakpatuhan terhadap peraturan perundang-undangan di bidang perpajakan dan hilangnya pendapatan pajak merupakan masalah yang menjadi perhatian serius para pembuat kebijakan pajak dan otoritas pajak yang relevan. Masalah kepatuhan pajak telah menjadi sebuah masalah penting di Indonesia karena jika Wajib Pajak tidak patuh dapat menimbulkan keinginan untuk

Pengaruh Insentif Pajak, Kualitas Pelayanan, dan Pemahaman Perpajakan Terhadap Kepatuhan Wajib Pajak 
mengambil tindakan menghindari dan mengabaikan pajak yang pada akhirnya akan merugikan negara yaitu penerimaan pajak berkurang.

Dunia sedang dilanda pandemi Covid-19 termasuk Indonesia. Disinilah pajak memiliki peran yang penting sebagai penopang APBN, sehingga belanja negara untuk memberikan manfaat seluasluasnya dapat terpenuhi. Terganggunya kegiatan ekonomi yang tidak berkesudahan ini membuat pemerintah manjalankan pajak sebagai fungsi budgetair melalui menerbitkan Peraturan Menteri Keuangan Nomor 9/PMK.03/2021 tentang Insentif Pajak untuk Wajib Pajak Terdampak Pandemi Corona Virus Disease 2019, salah satunya untuk Wajib Pajak UMKM.

Pemberian insentif pajak dalam situasi pandemi ini dapat mengedukasi Wajib Pajak UMKM mengingat manfaat nyata pajak yang dirasakan langsung oleh Wajib Pajak. Secara tidak langsung edukasi ini dapat meningkatkan kesadaran pajak yang akhirnya dapat meningkatkan kepatuhan pajak. Harapannya, adanya kebijakan pajak ini akan membantu Wajib Pajak bertahan di masa pandemi serta dapat menyejahterakan pihak yang akan merasakan manfaat kebijakan tersebut (Padyanoor 2020).

Faktor lainnya yang dinilai memperkuat kepatuhan pajak adalah kualitas pelayanan. Wajib Pajak dinilai akan patuh berdasarkan mutu pelayanan petugas pajak. Maka dari itu, aparat pajak senantiasa berbenah dalam memberikan pelayanan guna meningkatkan angka kepatuhan dengan meletakkan Wajib Pajak sebagai pelanggan yang harus dilayani dengan maksimal, layaknya pelanggan dalam organisasi komersial (Arifin \& Nasution 2017). Kualitas pelayanan yang dinilai dari keandalan, daya tanggap, jaminan, empati, dan bukti fisik memiliki implikasi bagi otoritas perpajakan dan pembuat kebijakan karena pengaruhnya terhadap perolehan penerimaan pajak untuk pertumbuhan dan pembangunan ekonomi (Susuawu, Kenneth \& John Amoh 2020).

Waib Pajak dinilai akan patuh apabila pemahaman perpajakannya memadai. Mengingat sistem pemungutan pajak yang diterapkan di Indonesia adalah self assessment system, maka Wajib Pajak sendiri yang menentukan besarnya pajak yang terutang. Kondisi tersebut dapat digunakan dalam mengukur perilaku Wajib Pajak dalam melaksanakan kewajiban perpajakannya (Anggraeni and Lenggono 2021). Kewajiban perpajakan harus dilaksanakan oleh Wajib Pajak sesuai dengan peraturan perundang-undangan di bidang perpajakan yang berlaku. Oleh karena itu, Wajib Pajak memerlukan pemahaman yang baik dan benar.

Fluktuasi jumlah Wajib Pajak UMKM yang tidak sejalan dengan angka kepatuhan Wajib Pajak UMKM memunculkan ketertarikan untuk meninjau faktor-faktor yang mempengaruhinya. Adanya insentif pajak yang disahkan baru-baru ini, baiknya kualitas pelayanan yang diberikan, dan pemahaman pajak yang memadai dipandang penting dalam meningkatan kepatuhan wajib pajak khususnya pada masa pandemi Covid-19. Berdasarkan permasalahan tersebut, penulis tertarik untuk meneliti pengaruh insentif pajak kualitas pelayanan, dan pemahaman perpajakan terhadap kepatuhan Wajib Pajak UMKM.

\section{METODE PENELITIAN}

Data penelitian ini merupakan data kuantitatif yang berupa skor atas jawaban yang diberikan oleh responden terhadap pernyataan dalam kuesioner. Kuesioner menggunakan 5 poin skala likert sebagai penentuan skor jawaban. Data primer dalam penelitian ini bersumber dari hasil jawaban kuesioner yang berasal dari Wajib Pajak UMKM baik orang pribadi maupun badan yang terdaftar di Kantor Pelayanan Pajak (KPP) Pratama Badung Selatan. Pengumpulan data dilakukan dengan metode kuesioner yang dibagikan peneliti secara langsung kepada responden di KPP Pratama Badung Selatan atas seijin KPP bersangkutan. Skala likert digunakan dalam menghitung bobot numerik hasil kuesioner. Populasi dalam penelitian ini adalah seluruh Wajib Pajak UMKM yang terdaftar di KPP

Pengaruh Insentif Pajak, Kualitas Pelayanan, dan Pemahaman Perpajakan Terhadap Kepatuhan Wajib Pajak 
Pratama Badung Selatan. Penentuan jumlag sampel ditentukan dengan menggunakan rumus Slovin. Jumlah sampel dalam penelitian ini adalah 100 Wajib Pajak UMKM dengan prosedur penentuan sampel menggunakan accidental sampling. Teknik analisis dalam penelitian ini menggunakan Structural Equation Modeling (SEM) berbasis Partial Least Square (PLS) dengan media SmartPLS 3.0 .

\section{HASIL DAN PEMBAHASAN}

Dalam penelitian ini pengujian validitas menggunakan convergent validity dan discriminant validity. Berdasarkan rule of thumb, untuk menilai convergent validity dilihat dari nilai loading factor lebih dari 0,7. Gambar 1 menunjukkan bahwa semua indikator dari masing-masing variabel memiliki nilai loading factor lebih besar dari 0,7 , maka indikator pada model dinyatakan valid.

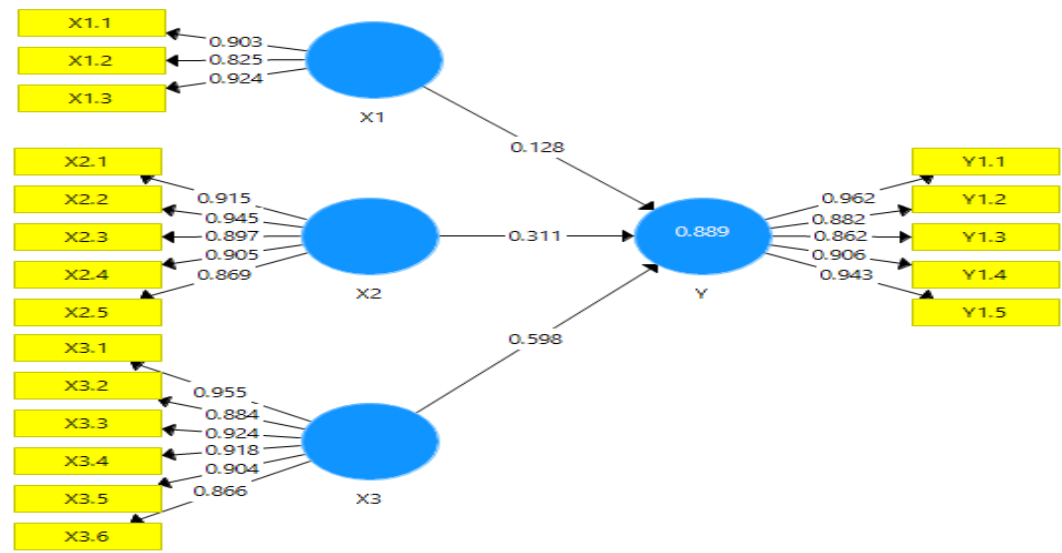

Sumber: Da ta diolah, 2021

\section{Gambar 1. \\ Path Diagram}

Selain dilihat dari nilai loading factor, nilai AVE pada setiap konstruk juga harus diperhatikan untuk memenuhi syarat convergent validity. Tabel 2 menunjukkan bahwa nilai AVE masing-masing variabel memiliki nilai lebih besar dari 0,5 , maka syarat convergent validity telah terpenuhi.

Table 2.

Average Variance Extracted $(A \mathrm{VE})$

\begin{tabular}{ll}
\hline & AVE \\
\hline InsentifPajak $\left(\mathrm{X}_{1}\right)$ & 0,783 \\
Kualitas Pelayanan $\left(\mathrm{X}_{2}\right)$ & 0,822 \\
Pemahaman Perpajakan $\left(\mathrm{X}_{3}\right)$ & 0,826 \\
Kepatuhan Wajib Pajak UMKM(Y) & 0,832 \\
\hline
\end{tabular}

Sumber: Data diolah, 2021

Selanjutnya dilakukan pengujian discriminant validity dengan melihat nilai cross loading setiap item konstruk. Tabel 3 menunjukkan nilai cross loading dari seluruh konstruk terhadap konstruknya telah lebih besar dibandingkan dengan korelasi item dari suatu konstruk ke konstruk lainnya. Maka hasil pehitungan telah memenuhi pengujian discriminant validity.

Pengaruh Insentif Pajak, Kualitas Pelayanan, dan Pemahaman Perpajakan Terhadap Kepatuhan Wajib Pajak 
Table 3.

Cross loading

\begin{tabular}{lcccc}
\hline & Insentif Pajak $\left(\mathbf{X}_{\mathbf{1}}\right)$ & $\begin{array}{c}\text { Kualitas Pelayanan } \\
\left(\mathbf{X}_{\mathbf{2}}\right)\end{array}$ & $\begin{array}{c}\text { Pemahaman } \\
\text { Perpajakan }\left(\mathbf{X}_{\mathbf{3}}\right)\end{array}$ & $\begin{array}{c}\text { Kepatuhan Wajib Pajak } \\
\text { UMKM(Y) }\end{array}$ \\
\hline X1.1 & 0,903 & 0,643 & 0,614 & 0,694 \\
X1.2 & 0,825 & 0,686 & 0,441 & 0,566 \\
X1.3 & 0,924 & 0,615 & 0,536 & 0,633 \\
X2.1 & 0,655 & 0,915 & 0,625 & 0,757 \\
X2.2 & 0,733 & 0,945 & 0,671 & 0,810 \\
X2.3 & 0,636 & 0,897 & 0,597 & 0,700 \\
X2.4 & 0,621 & 0,905 & 0,526 & 0,697 \\
X2.5 & 0,651 & 0,869 & 0,810 & 0,801 \\
X3.1 & 0,612 & 0,724 & 0,955 & 0,882 \\
X3.2 & 0,456 & 0,532 & 0,884 & 0,732 \\
X3.3 & 0,573 & 0,679 & 0,924 & 0,824 \\
X3.4 & 0,607 & 0,721 & 0,918 & 0,861 \\
X3.5 & 0,457 & 0,579 & 0,904 & 0,774 \\
X3.6 & 0,573 & 0,658 & 0,866 & 0,815 \\
Y1.1 & 0,685 & 0,772 & 0,890 & 0,962 \\
Y1.2 & 0,669 & 0,700 & 0,771 & 0,882 \\
Y1.3 & 0,632 & 0,833 & 0,786 & 0,862 \\
Y1.4 & 0,609 & 0,717 & 0,812 & 0,906 \\
Y1.5 & 0,672 & 0,777 & 0,834 & 0,943 \\
\hline
\end{tabular}

Sumber: Data diolah, 2021

Dalam menilai discriminant validity, selain menggunakan angka cross loading juga dilakukan pengujian dengan membandingkan akar kuadrat dari AVE setiap konstruk dalam model dengan korelasi antar konstruk lainnya. Tabel 4 menunjukkan nilai akar kuadrat AVE dari suatu konstruk lebih besar daripada korelasi antar kosntruk maka pengujian discriminant validity telah terpenuhi.

Table 4.

Nilai Korelasi Antar Konstruk

\begin{tabular}{lcccc}
\hline & Insentif Pajak $\left(\mathrm{X}_{1}\right)$ & $\begin{array}{c}\text { Kualitas } \\
\text { Pelayanan }\left(\mathrm{X}_{2}\right)\end{array}$ & $\begin{array}{c}\text { PemahamanPerpajakan } \\
\left(\mathrm{X}_{3}\right)\end{array}$ & $\begin{array}{c}\text { Kepatuhan Wajib Pajak } \\
\text { UMKM (Y) }\end{array}$ \\
\hline $\mathrm{X}_{1}$ & 0,885 & & & \\
$\mathrm{X}_{2}$ & 0,729 & 0,907 & & \\
$\mathrm{X}_{3}$ & 0,605 & 0,718 & 0,909 & 0,912 \\
$\mathrm{Y}$ & 0,717 & 0,834 & 0,899 & 0,89 \\
\hline
\end{tabular}

Sumber: Data diolah, 2021

Table 5.

Nilai Cronbach's Alpha dan Composite Reliability

\begin{tabular}{lcc}
\hline & Cronbach's Alpha & $\begin{array}{c}\text { Composite } \\
\text { Reliability }\end{array}$ \\
\hline Insentif Pajak $\left(\mathrm{X}_{1}\right)$ & 0,861 & 0,915 \\
Kua litas Pelayanan $\left(\mathrm{X}_{2}\right)$ & 0,946 & 0,958 \\
Pemahaman Perpajakan $\left(\mathrm{X}_{3}\right)$ & 0,958 & 0,966 \\
Kepatuhan Wajib Pajak UMKM(Y) & 0,949 & 0,961 \\
\hline
\end{tabular}

Sumber: Data diolah, 2021

Pengaruh Insentif Pajak, Kualitas Pelayanan, dan Pemahaman Perpajakan Terhadap Kepatuhan Wajib Pajak 
Uji reliabilitas dapat dilihat dari nilai cronbach's alpha dan composite reliability. Tabel 5 menunjukkan nilai lebih besar dari 0,7 dapat disimpulkan syarat reliabel telah dipenuhi oleh seluruh variabel.

Tabel 6 memperlihatkan bahwa nilai R-square sebesar 0,889, berdasarkan kriteria maka model tersebut termasuk model yang kuat, maknanya kepatuhan Wajib Pajak UMKM mampu dijelaskan oleh insentif pajak, kualitas pelayanan, dan pemahaman perpajakan sebesar $88,9 \%$, sisanya $11,1 \%$ dijelaskan oleh variabel di luar model.

Table 6.

Nilai $R$-square

\begin{tabular}{lc}
\hline & R-square \\
\hline Kepatuhan Wajib Pajak UMKM(Y) & 0,889 \\
\hline Sumber: Data diolah, 2021
\end{tabular}

Sumber: Data diolah, 2021

Nilai path coefficient mengindikasikan arah pengaruh variabel eksogen terhadap variabel endogennya. Tingkat signifikansi yang digunakan adalah 5\% dengan nilai T-tabel 1,96. Nilai Tstatistik > 1,96 menunjukkan hipotesis diterima, sedangkan jika nilai T-statistik $<1,96$ menunjukkan hipotesis ditolak.

Table 7.

Nilai Bootstrapping

\begin{tabular}{lccc}
\hline & $\begin{array}{c}\text { Path } \\
\text { Coefficients }\end{array}$ & T-statistics & $\begin{array}{c}\text { Probability } \\
\text { Value }\end{array}$ \\
\hline InsentifPajak $\left(\mathrm{X}_{1}\right)$-> Kepatuhan Wajib Pajak UMKM $(\mathrm{Y})$ & 0,128 & 2,064 & 0,040 \\
Kua litas Pelayanan $\left(\mathrm{X}_{2}\right)$-> Kepatuhan Wajib PajakUMKM(Y) & 0,311 & 2,548 & 0,011 \\
Pemahaman Perpajakan $\left(\mathrm{X}_{3}\right)$-> Kepatuhan Wajib Pajak UMKM(Y) & 0,598 & 6,090 & 0,000 \\
\hline Sumber: Data diolah 2021
\end{tabular}

Sumber: Data diolah, 2021

Insentif pajak (X1) memiliki pengaruh positif dengan nilai path coefficients 0,128 dan signifikan dengan nilai T-statistic 2,064 terhadap kepatuhan Wajib Pajak UMKM (Y). Kualitas Pelayanan (X2) memiliki pengaruh positif dengan nilai path coefficients 0,311 dan signifikan dengan nilai T-statistic 2,548 terhadap kepatuhan Wajib Pajak UMKM (Y). Pemahaman perpajakan (X3) memiliki pengaruh positif dengan nilai path coefficients 0,598 dan signifikan dengan nilai $\mathrm{T}$-statistic 6,090 terhadap kepatuhan Wajib Pajak UMKM (Y).

Insentif pajak (X1) memiliki pengaruh positif dan signifikan terhadap kepatuhan Wajib Pajak UMKM (Y). Hasil penelitian ini sejalan dengan penelitian Latief et al. (2020), pemberian insentif pajak mampu meningkatkan kepatuhan pajak di KPP Pratama Makassar Selatan (Latief, Zakaria, and Mapparenta 2020). Penelitian Alfina dan Diana (2020) juga mengungkapkan bahwa insentif pajak efektif dalam menaikkan kepatuhan Wajib Pajak termasuk dalam menyampaikan Surat Pemberitahuan Tahunan (SPT) di KPP Pratama Malang Utara (Alfina \& Diana 2020). Penelitian Rachmawati dan Ramayanti (2016) juga mengungkapkan bahwa pemberian keringanan pajak memberikan manfaat yang besar dalam peningkatan kepatuhan UMKM di Kawasan Jakarta Selatan (Rachmawati \& Ramayanti 2016). Pada masa pandemi Covid-19, pemerintah menggelontorkan dana secara besarbesaran untuk keperluan menghadapi dampak pandemi Covid-19. Semakin tinggi insentif pajak yang diberikan oleh pemerintah, maka Wajib Pajak akan memiliki kesadaran akan manfaat nyata pajak

Pengaruh Insentif Pajak, Kualitas Pelayanan, dan Pemahaman Perpajakan Terhadap Kepatuhan Wajib Pajak 
secara langsung dalam menghadapi pandemi Covid-19. Sehingga masayarakat semakin sadar pentingnya pajak bagi sebuah negara dan meningkatkan kepatuhannya untuk membayar pajak.

Kualitas pelayanan (X2) memiliki pengaruh positif dan signifikan terhadap kepatuhan Wajib Pajak UMKM (Y). Hasil penelitian ini sejalan dengan penelitian Riadita dan Saryadi (2019) bahwa pelayanan baik yang diberikan petugas pajak mampu memberikan motivasi Wajib Pajak di KPP Pratama Semarang Selatan (Riadita \& Saryadi 2019). Penelitian Puspanita et al. (2020) juga menyebutkan melalui tingginya tingkat kualitas pelayanan petugas pajak terjadi peningkatan kepatuhan Wajib Pajak UMKM di Kota Cilegon (Puspanita, Machfuzhoh, \& Pratiwi 2020). Begitu juga dengan penelitian yang dilakukan oleh Machfuzhoh dan Pratiwi (2021) mengungkapkan bahwa pelayanan yang baik mampu meningkatkan angka kepatuhan UMKM (Machfuzhoh \& Pratiwi 2021). Sering kali Wajib Pajak memiliki kendala ataupun kurang memadainya pemahaman yang dimilikinya. Petugas pajak cepat tanggap terhadap kendala yang dihadapi UMKM dan menjunjung profesionalitas kinerja. Ketika petugas pajak memiliki pemahaman yang memadai akan peraturan di bidang perpajakan, maka dapat meringankan permasalahan Wajib Pajak UMKM dengan memberikan informasi dan solusi yang mudah dimengerti. Wajib Pajak merasa nyaman dan mudah akan pelayanan yang diberikan yang kemudian akan berdampak pada reaksi dan perilakunya. Reaksi dan perilaku tersebut berupa kepatuhan perpajakan. Semakin Wajib Pajak terpenuhinya kepuasan akan pelayanan yang diperoleh, maka akan tingkat kepatuhannya akan meningkat pula.

Pemahaman perpajakan (X3) memiliki pengaruh positif dan signifikan terhadap kepatuhan Wajib Pajak UMKM (Y). Hasil penelitian ini sejalan dengan penelitian Machfuzhoh dan Pratiwi (2021) yang mengungkapkan bahwa dengan pemahaman pajak yang memadai, para UMKM yang terdaftar di KPP Pratama Cilegon akan memenuhi kewajiban perpakakannya (Machfuzhoh \& Pratiwi 2021). Penelitian Sugiartini et al. (2020) menjelaskan bahwa pelaksanaan kewajiban perpajakan Wajib Pajak dapat terpenuhi dengan baik apabila memiliki pemahaman yang baik mengenai peraturan perpajakan yang berlaku (Sugiartini, Hardika, \& Aryaningsih 2020). Begitu juga dengan penelitian Anggraeni dan Lenggono (2021) yang menyimpulkan bahwa pemahaman pajak yang mencukupi akan membuat UMKM yang terdaftar di KPP Pratama Ambon menjadi taat pajak (Anggraeni \& Lenggono 2021). Makna pemahaman perpajakan yaitu Wajib Pajak memahami sepenuhnya ketentuan perpajakan, baik sistem, prosedur, dan fungsi serta mampu mengaktualkan pengetahuan tersebut dalam melaksanakan kewajiban perpajakannya. Pemahaman perpajakan sebagai aspek penting dalam membentuk kepatuhan, karena jika Wajib Pajak kurang memahami perpajakan, maka akan menimbulkan ketidakpercayaan dan ketidakpatuhan. Pemahaman perpajakan akan menumbuhkan kesadaran bagi Wajib Pajak UMKM akan pentingnya membayar pajak untuk bangsa Indonesia.

\section{SIMPULAN DAN SARAN}

Berdasarkan hasil analisis dan pembahasan, maka dapat dapat disimpulkan sebagai berikut: insentif pajak memiliki pengaruh positif dan signifikan terhadap kepatuhan Wajib Pajak UMKM, kualitas pelayanan memiliki pengaruh positif dan signifikan terhadap kepatuhan Wajib Pajak UMKM, dan pemahaman perpajakan memiliki pengaruh positif dan signifikan terhadap kepatuhan Wajib Pajak UMKM. Adapun saran dari hasil penelitian ini adalah pemberian insentif pajak oleh pemerintah diharapkan mampu menumbuhkan kesadaran pajak bagi Wajib Pajak UMKM. Apabila terdapat permasalahan dalam pemenuhan kewajiban perpajakannya, Wajib Pajak UMKM dapat memanfaatkan layanan yang diberikan petugas melalui tatap muka secara langsung ataupun melalui media komunikasi chat atau telepon yang telah disediakan pada masing-masing kantor pelayanan. Adanya

Pengaruh Insentif Pajak, Kualitas Pelayanan, dan Pemahaman Perpajakan Terhadap Kepatuhan Wajib Pajak 
insentif pajak sangat membantu Wajib Pajak UMKM bangkit di tengah ekonomi yang lesu akibat pandemi Covid-19. Pemberian insentif pajak masih perlu dievaluasi terkait dengan persyaratan, jangka waktu pemberian insentif, dan juga utamanya dalam sosialisasi kepada Wajib Pajak. Selain itu, otoritas pajak senantiasa berbenah akan pelayanan kepada Wajib Pajak baik secara langsung maupun daring guna menciptakan kenyamanan Wajib Pajak. Penelitian berikutnya diharapkan dapat menganalisis kembali kepatuhan Wajib Pajak UMKM. Hal tersebut dapat dilakukan dengan melakukan pertimbangan untuk menambah jumlah responden, pengembangan indikator, penambahan variabel, serta penambahan item pertanyaan.

\section{REFERENSI}

Alfina, Zuli, and NurDiana. (2020). Pengaruh Insentif Perpajakan Akibat Covid-19, Pemahaman Perpajakan, Kesadaran Wajib Pajak Terhadap Kepatuhan Wajib Pajak Dalam Menyampaikan Su rat Pem berit ahuan Tahunan (Studi Pada Wajib Pajak Yang Terdaftar Di Kpp Pratama Malang Utara). E-Jra 9(2):47-57.

Anggraeni, Vinska KiKi, and Tirza Oktovianti Lenggono. (2021). Pengaruh Imple mentasi PP No 23 Ta hu n 2018, Pemahaman Perpajakan, Dan Modernisasi Sistem Administrasi Perpajakan Terhadap Ke pat uhan Wajib Pajak UMKM(Studi Empiris Pada Wajib Pajak Orang Pribadi UMKM Di Kota Am bon). Jurnal Akuntansi: Transparansi Dan Akuntabilitas 9(1):96-108.

Appah, Ebimobowei, andElizabeth C. Wosowei. (2016). Tax Compliance Intentions a nd the Behaviou r of the Individual Taxpayer: Evidence from Nigeria. Research Journal of Finance and Accounting 7(13):1-9.

Arifin, Syamsul Bahri, and Aulia Arief Na sution. (2017). Pengaruh Kualitas Pelayanan Dan SanksiPerpajakan Terhadap Kepatuhan Wajib Pajak Badan Di KPP Pratama Medan Belawan. Jumal Akuntansi Dan Bisn is 3(2):177-86. doi: https://doi.org/10.31289/jab.v3i2.1237.

Latief, Salman, Junaidin Zakaria, and Mapparenta. (2020). Pengaruh Kepercayaan Kepada Pemerintah, Kebijakan Insentif Pajak Dan ManfaatPajak Terhadap Kepatu han Wajib Pajak. CESJ : Center Of Economic Students Journal 3(3):270-89.

Listyowa ti, and YuliChomsatu Samrotun Suhendro. (2018). Faktor-Faktor Yang Mempen garuhi Ke patuhan Wajib Pajak Dalam Membayar Pajak. Jurnal Riset Akuntansi Dan Bisnis Airlangga 3(1):372-95. doi: 10.31093/jraba.v3i1.94.

Machfuzhoh, Asih, and Refi Pratiwi. (2021). The EffectOf Understanding Taxation Regulations, Tax Rates, Tax Sanctions, Tax Socialization, Fiscus Services And Online Services On The Level Of Complia nce Wit h MSME Taxpayers. Jurnal Riset Akuntansi Terpadu 14(1):1-15. doi: 10.35448/jrat.v14i1.10416.

Padyanoor, Aswin. (2020). Kebijakan Pajak Indonesia Menanggapi Krisis COVID-19: Manfaat B agi Wa jib Pajak. E-Jumal Akuntansi 30(9):2216.

Puspanita, Intan, Asih Machfuzhoh, and Refi Pratiwi. (2020). Pengaruh Kualitas Pelayanan Terhadap Kepatuhan Wajib Pajak UMKM. Pp. 71-78 in Prosiding SimposiumNasionalMultidisiplin.

Rachmawati, Nurul Aisy ah, and Rizka Ramayanti. (2016). Manfaat Pemberian Insentif Pajak Penghasilan Dalam Kepatuhan Wajib Pajak UMKM. JurnalAkuntansi, Ekonomi, Dan Manajemen Bisnis 4(2): 176-85.

Riadita, Farah Alifa, and Saryadi. (2019). Pengaruh Kualitas Pelayanan, Kesadaran Wajib Pajak, Dan Pengeta huan Pajak Terhadap Kepatuhan Wajib Pajak (Studi Pada Umkm Yang Terdaftar Di KPP Prata ma Sema rang Selatan). Jurnal Ilmu Administrasi Bisnis 8(2):105-13.

Sugiartini, N. L. M., N. S. Hardika, and N. N. Aryaningsih. (2020). The Effect of Taxation Understanding a nd Taxpayer Attitudes on Taxpayer Compliance with Implementation of E-Filing Sy stem as Mediation Va riable. Journal of Applied Sciences in Accounting, Finance, and Tax 3(1):19-29.

Susuawu, Daniel, Ofori-Boateng Kenneth, and John Amoh. (2020). Does Service Quality Influence Tax Compliance Behaviour of SMEs? A New Perspective from Ghana. International Jou rn al of Economics and Financial 10(6):50-56. doi: 10.32479/ijefi.10554.

Pengaruh Insentif Pajak, Kualitas Pelayanan, dan Pemahaman Perpajakan Terhadap Kepatuhan Wajib Pajak 